\title{
Mapping Industrial Heritage Sites in Egypt: Identification \& Management
}

Shreen Mohamed Amin, Hosam Refai and Rasha Kamal\&

\begin{abstract}
The emphasis in this paper is on analyzing the context of industrial heritage in Egypt. The context of Industrial heritage reveals identity, cultural traditions and memories of work, a fundamental part of industrial culture. It is a part of urban transformation in the city, and its planning practices. ${ }^{1}$ In the last 30 years, awareness of the importance of industrial heritage in understanding history increased, and the new definition of Industrial Heritage started representing meaning in our history. The industrial heritage in Egypt is an important point of analysis as it could offer economic, cultural, and social benefits to the community. The objective of this research is to examine the context of industrial heritage in Egypt and find effective strategies for raising awareness of its importance. The paper sheds light on the Laws and legal procedures for managing the industrial heritage in Egypt, and the ways to document the industrial heritage tools, devices, mechanisms. Then, the paper presents a management plan for the Egyptian industrial heritage that could contribute to safeguard, interpret, and promote such aspects of cultural heritage.
\end{abstract}

\section{Key Words:}

Mapping - industrial Heritage - Context - Document

\section{Introduction}

The TICCIH ${ }^{2}$ charter, Nizhny Tagil Charter, for the identification and protection of industrial heritage that was signed in Moscow 2003 by TICCIH organization and ICOMOS ${ }^{3}$ states the importance of recording the physical features and condition of the objects of industrial heritage especially in the industrial sites; such recording should be placed in a public archive because they provide evidence of activities, tell stories, and increase our sense of identity and understanding of cultures. The TICCIH charter sheds light on the process of recording such types of heritage that should include "written descriptions, drawings, photographs and video film of moving objects, and references to supporting documentation". TICCIH charter highlights the intangible aspects of industrial heritage where the working memories of people involved in any industrial activity are unique and irreplaceable resources and should be recorded because these memories elaborate their social activities, as well as the intangible records of any industrial activity contained in memories. TICCIH charter states the importance to identify the extent of the industrial heritage where any particular industrial typologies should be analyzed and documented; then such documentation should be freely accessible to the public. ${ }^{4}$ Policies for the protection of the industrial heritage should be added to the programs of historical research. Such policies are the way to safeguard many industrial activities in various sites. TICCIH charter identifies the criteria for assessing industrial heritage; the criteria identify the most important existing landscapes, sites, settlements, buildings, structures, machines , and processes. The charter also sheds light on the importance of listing strong legal measures that ensure the conservation of industrial heritage. TICCIH charter states the tremendous impact that industrialization has had on human culture, where all these aspects should be considered by The World Heritage List of UNESCO.

Measures for maintaining and conserving the Industrial heritage depend on the preservation of the functional integrity of such kind of heritage. The Measures for conserving the Industrial heritage requires a thorough knowledge of the various

\footnotetext{
1 Heike Oevermann, Industrial heritage management in the context of urban planning (Georg-Simmel-Center for Metropolitan Studies Berlin, Germany, Big Stuff, accessed October 31, 2019, 2-4, https://bigstuff.omeka.net/items/show/17,

2 TICCIH stands for the Nizhny Tagil Charter for the Industrial Heritage signed in Moscow in 2003 by TICCIH organization and ICOMOS TICCIH The Nizhny Tagil Charter for the Industrial Heritage (Moscow, 2003), 1-4, accessed December 10, 2020 https://www.icomos.org/18thapril/2006/ nizhny-tagil-charter-e.pdf

3 ICOMOS stands for International Council on Monuments and Sites, ICOMOS was founded in 1965 in Warsaw as a result of the Venice Charter of 1964 , and offers advice to UNESCO on World Heritage Sites, accessed December 10, 2020 https://www.icomos.org/en,

4. TICCIH the Nizhny Tagil Charter for the Industrial Heritage, 3-4.
} 
industrial processes which may have taken place in the industrial sites. The various industrial processes include all the former uses that should be examined and assessed. TICCIH charter states the possibility of the rehabilitation and possible adaptation of an industrial site to ensure its conservation, and this possibility couldn't be accepted if the site has an especial historical significance where the original patterns of circulation and activity of such kind of heritage should be respected. It highlights the importance of conserving the human skills involved in many industrial processes that should be carefully recorded and transmitted to younger generations.

The Industrial Heritage Analysis that was conducted by the UNESCO ${ }^{5}$ World Heritage Centre Asia-Pacific Region states that the category "Industrial Heritage" is an under-represented category of cultural (including industrial), natural and mixed sites and inscribed on the UNESCO World Heritage List. In 1999, the World Heritage Centre in collaboration with ICOMOS listed. The classification of World Heritage sites that included Industrial Heritage sites. This list was decided upon and decreed by the UNESCO World Heritage Centre annually ${ }^{6}$. Industrial Heritage is considered by the World Heritage Committee and the ICOMOS analysis as an under-represented category on the World Heritage List. The Industrial Heritage Analysis of the UNESCO World Heritage Centre Asia-Pacific states that "Only certain types of cultural property are represented excessively on the World heritage list and that Industrial heritage is one of the poorly represented types as well as the 20th century heritage; therefore, several factories, mines, forges and manufactures have been listed on the World Heritage List. The Industrial Heritage Analysis of the UNESCO World Heritage Centre Asia-Pacific defines Industrial heritage as "The Industrial Revolution that profoundly modified lifestyles and landscapes, and the means employed to extract raw materials and exploit the agricultural products and minerals resulted in grandiose constructions and great achievements, testifying to the creative genius
of humankind where Industrial sites are important milestones in the history of humanity. Therefore, they embody the hope of a better life and the ever-greater power over matter. ${ }^{7}$ The classification of World Heritage sites was initially prepared in 1999 by the World Heritage Centre in collaboration with ICOMOS. It included 28 sites that are considered Industrial Heritage where such kind of heritage embraces $5.3 \%$ of all cultural sites and $4 \%$ of all World Heritage Sites. ${ }^{8}$ The Industrial Heritage Analysis such kind of heritage embraces $5.3 \%$ of all cultural sites and $4 \%$ of all World Heritage Sites. ${ }^{.}$The Industrial Heritage Analysis
of the UNESCO World Heritage Centre Asia-Pacific also sheds light on the difference of the cultural components (including of the UNESCO World Heritage Centre Asia-Pacific also sheds light on the difference of the cultural components (including
industrial) of each region. UNESCO World Heritage Centre Asia-Pacific Analysis listed twenty-eight inscribed industrial industrial) of each region. UNESCO World Heritage Centre Asia-Pacific Analysis listed twenty-eight inscribed industrial
heritage sites classified by region; twenty-two of which are found in Europe /North America regions, four in both Latin America /Caribbean region, and two in Asia/Pacific region. According to the list, there are no Industrial Sites on the World Heritage List in Africa and the Arab States. (Diagrams 1,2)

The testimonies of industrialization have played an important role in both urban and rural territorial evolution, forming the historical and cultural character of its sites, places, and landscapes. Each Architectural design, landscape, industrial facility or machinery has a character that should be kept alive in any process of intervention, recovery, rehabilitation, or restoration. ${ }^{9}$ The Industrial Heritage Analysis of UNESCO World Heritage List identifies the Tentative Industrial World Heritage Sites in the Arab States, figure 1 expresses the map of this Tentative list ${ }^{10}$ where no Industrial Heritage sites are on the List, and only three Industrial Heritage Sites with very special topics are listed as mixed sites on the Tentative List; the three mixed sites are bulk products industries with a commercial center for metallurgical industry of gold, iron and copper in Mauritania, power sources and prime movers, There is an exceptional water wheel system in Hama, Syria, specialized structures and objects shows at "Aflaj" "1 ground and subterranean canal system in Oman. ${ }^{2}$ Figures 2-3 show the associated industrial value sites

In the Middle East, Saudi Arabia is the first country to set an association for the preservation of Industrial Heritage under the authority of Prince Badr bin Abdullah bin Farhan, the Saudi Minister of Culture. The association aims to shed light on the industrial heritage in the Arab region, raise community awareness on the value of cultural industry landmarks. The Saudi Minister of Culture stated the plan of this association. The plan included Workshops and awareness campaigns in cooperation with industrial bodies in the Arab region. The policy of association is focused on maintaining and documenting industrial landmarks in cooperation with international universities. The first meeting for this massive project was held on Sunday, July 14, 2019. Prince Badr bin Abdullah bin Farhan stated that the first step is to establish the first national database for all industrial

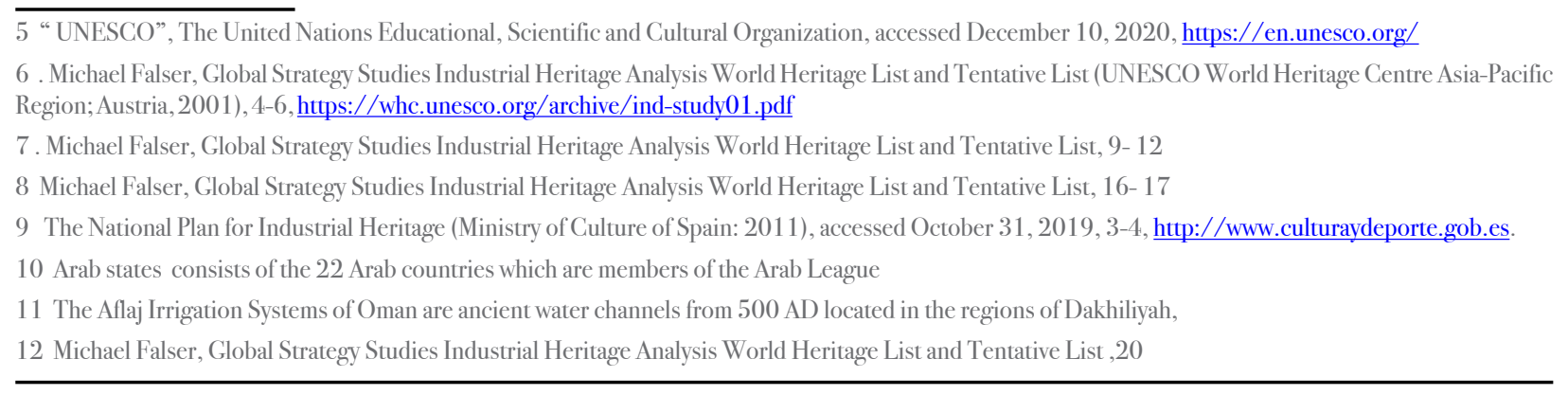

sites in Saudi Arabia; then in the Arab region. He also announced a competition for the industrial bodies where participants are requested to send pictures, videos, and basic information about the cultural industry landmarks in Saudi Arabia; then the would tell stories and perform detailed events that affected the industry and social life through voice recording or videos. Soudi The mission of the ministry is to focus on the current and new industry in Foypt as the engine of sustaindustral bodies. The mission af he ming economic developing industries, developing the industrial zones system, building environmentally friendly industrial cities, reco industrial cities, as well as transforming them to serve the oreen industry grection Deprent. Tourism \& Antiquities and the Herita Mange touries the Egyptian Prime Minster to the Egyptian Prime list in the industrial type. ${ }^{16}$

Main Features of the Foyptian Industry are points of analysis. Egypt has witnessed an industrial renaissance in the $19^{\text {th }}$ century by "Muhammad Ali" whose era is known for the establishment of a major industrial base, which included textiles and suge industry production of oils, rice mills, and military industries, where the sumar industry started in 1835 , the textile industr. 1911, and phosphate fertilizers in 1937. The iron industry started in 1948, nitrogenous fertilizers in 1951 and all these activities were based on the efforts of the private sector such as Banque Misr which was established in $1920 .{ }^{17}$ Since 1948 , there were several attempts to manufacture iron and steel, where three companies were established: the Egyptian copper factories, the several attempts to manufacture iron and steel, where three companies were established: the Egyptian copper factories, the
Delta Steel factories, and the National Company for Metal Industries. The Foyptian Iron and Steel Company was the first inteorated project that elabor

Several industrial heritage contexts are identified in Egypt, analyzing such cases reveals the different core values of the industrial heritage of Egypt. The first case of the industrial heritage contexts in Egypt is traced in the Red Sea Governorate (Al Qusayr) a city in eastern Egypt, located on the Red Sea coast. The old factories of the phosphate industry dating back to 1910 reflect the industrial heritage context in that governorate. First examples of a case are the factories of Al Qusayr which reveal the importance of the Egyptian industrial heritage in safeguarding the identity of the Red Sea Governorate, ensuring that one of the major industries is the Phosphate industry. Figures 6-7-8 show the current situation of one of the old Phosphate factories of A Qusayr, where industrial devices dating back to the $19^{\text {th }}$ century in Egypt were used in Phosphate production, in a very bad condition where the owning company sold old machinery as scrap ${ }^{18}$ Other industrial devices could be found in $\mathrm{Al}$ Qusayr citadel, a historical castle built during the Ottoman era by Sultan Selim II to protect pilgrims and commercial caravans. Near the easter tower of the citadel, old mining tools are on display focusing on the phosphate company of Al Qusayr that was established by Italians Engineers in 1916. Figures 9-10 show the carriages that were used to transport phosphates in the early $20^{\text {th }}$ century the carriages were gifts by the Al Quseir Phosphate Company. The citadel is now under the authority of the Egyptian Ministry of Tourism\&Antiquities. ${ }^{19}$

The second case of industrial heritage contexts in Egypt is the Minet El-Bassal region nearby the Mahmoudiya Canal, Alexandria Port. It was a famous Alexandrian Industrial district till the issuance of the decree N.36 in 1967 by the former presiden Gamal Abdel Nasser. The decree aims to end the enforcement of the Stock Exchange of Minet El-Bassal as the main center for

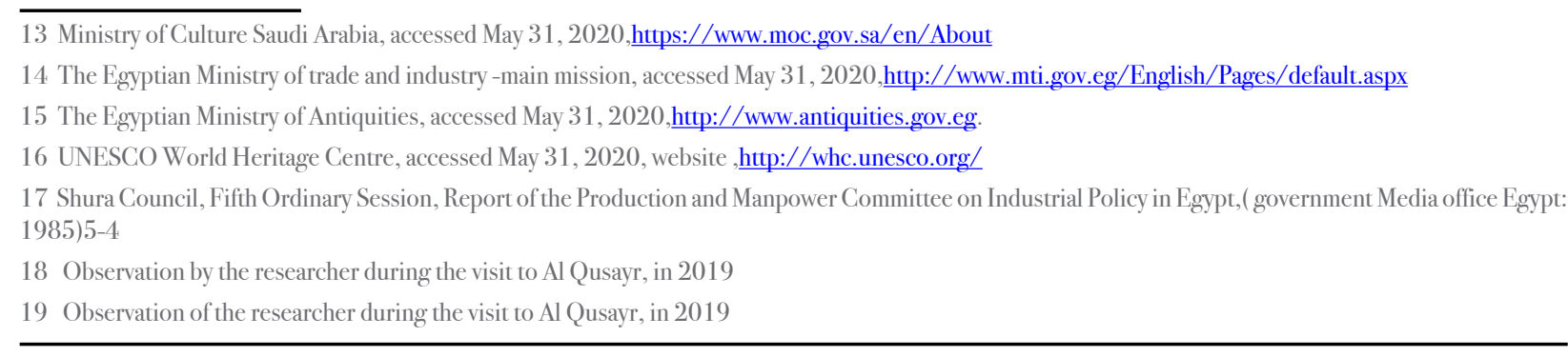


the cotton industry in Egypt. ${ }^{20}$ The region of Minet El-Bassal was established in 1810, housing the international trade center headquarters; it was a world marketing center for Egyptian cotton. Many of the cotton factory buildings in Minet El-Bassal region are on their way to be demolished because of the lack of awareness of aspects of Egyptian industrial heritage. Such aspects are safeguarding the physical remains of the history of industry and social activities related to industry. Dina Mamdouh Nassar, Shahira Sharaf Eldin stated in their article published by the journal of heritage conservation, that Minet El-Bassal was supported by a transportation network in Alexandria, where the railway used for freight was built in the 1850s to serve the western port. This is reflected the extensive industrial development in this area. ${ }^{21}$

The third case of the industrial heritage contexts in Egypt are the factories of textile manufacturing at El Mahalla El Kobra, El Gharbeya Governorate. Textile machinery had been in operation since 1927 when Misr Spinning and Weaving was established, as one of Banque Misr companies founded by "Talaat Harb" in 1920 when the company named Misr Spinning and Weaving began production in 1930 and the number of its spindles was 12,200 , reaching 300,000 spindles, including six spinning factories. At the beginning it also contained 484 looms of textiles. Several industrial devices of El Mahalla El Kobra factories are historical industrial devices such as its machines that had been used since 1875 in ginning and other machines used since 1810 in spinning; the latter machines were manufactured in England and were introduced into Egypt 212 years ago. 22 Figure 11 shows one of the industrial heritage machines used in Egypt in Cotton spinning, made by the British Sir Richard Arkwright (23 December 1732 - 3 August 1792) who was a leading entrepreneur and an English inventor during the early Industrial Revolution. ${ }^{23}$ This machine enables the spinning of 12 threads only by one person; it is worth pointing out that the Egyptian Ministry of Public Business Sector stated in 2019 the plan ${ }^{24}$ of the Texile factories' development in El Mahalla EI Kobra. 25

The fourth case of the industrial heritage contexts in Egypt is a printing machine that could be traced at Khan Al-Zarakhsheh and Al-Subaih, Al-Azhar Street Cairo, Al-Sabeeh Library and Print House is one of the distinctive places at Al-Azhar Street. The early printer used in the print house of Al-Sabeeh Library reveals the value of the industrial devices used during the 18th century in Egypt. ${ }^{20} \mathrm{~A}$ printing machine dating back to the 19th century was used in the activites of Al-Sabeeh Library; it is keptnowadays under the authority of the Egyptian Ministry of Tourism \& Antiquities( Historic Cairo Project Sector). Figures 12-13 show the display of the 19th - century printing machine in one of the old structures of Al-Azhar Street; under the authority of the Historic Cairo Project Sector. ${ }^{27}$

The fifth case of the industrial heritage contexts in Egypt is traced to El Faiyum, a city in Middle Egypt; in 1936, where a hydraulic power station was built, and began producing electricity by 1940 . The station used to supply many villages with electricity such as Atsa Center and a major part of El Faiyum Governorate with electricity, Al Gharaqat region and a major part of EI Faiyum Governorate, Faiyum Governorate, in addition to levitation levitating of water to about 5,000 agricultural lands for the family of Muhammad Ali pasha. The station generates electricity with a capacity of 33 thousand watts on seven waterfalls. This station was operating until 1971 and was supplying electricity to three distribution stations; it includes stores, workshops, and rooms the station has a DC battery room to be used in lighting the station for during maintenance work or malfunction. New and old 20 Dina Mamdouh Nassar, Shahira Shara Eldin, A new life for the industrial heritage of Minet el-Bassal at Alexandria (Wiadomości Konserwatorskie, The
Journal of Heritage Conservation: 2013) 2-6. accessed May 31, 2020, hthps://inta-aivn.org /images /cc/Transmed/NassarD NewLife.pdf 21 Dina Mamdouh Nassar, Shahhira Sharaf Eldin, A new life for the industrial heritage of Minet el-Bassal at Alexandria, 5 accessed May 31, 2020, htups:// (a)

22 L.A. Fridman's Yegipyet, Capitalist development in Egypt\& the Egyptian working class 1939-1882, trans.Dr. Zuhdi Al-Shami (New World Publishing louse: Egypt, 1985

rkwright (1732 - 1792)". BBC Historic Figures, accessed May 31, 2020, hthps://www.bbc.co.uk/history/historic figures/arkwright.

24 Egypr's Ministry of the Public Business Sector has launched a new plan to restructure all textile companies, reduce the companies' losses, According to and to boost the sector The plan also involves establishing four new factories, modernizing old equipment in existing factories, and providing training for worker.

25 The official site of the Ministry of the public sector in Egypt, accessed May 31, 2020, http://www.sis.gov.egy/Story/99611/Ministry-of-Public-Business-
ector

26 The Sabeeh family is an Egyptian family that worked in printing for nearly two centuries untilit decided to stop its activity and only a printing machine dating

Historical Cairo project reports, accessed May 31, 2020, hthps:// whc. unesco.org turbines are still accessible at El Faiyum (figures 14-17) ${ }^{20}$ The sixth case of the industrial heritage contexts in Egypt is located at Helwan where the former President Gamal Abdel Nasser
issued a decree establishing the first integrated steel production complex as an Iron and Steel Company on June 14, 1954 at issued a decree establishing the first integrated steel production complex as an Iron and Steel Company on June 14,1954 at
Al-Tebeen district, in Helwan .Besides, Al Nasr Auto Factory was one of the major factories dating back to 1958 ; it was in the Wadi Hof areaarea, next to a primary source of raw material, represented in the Tebeen iron and steel factory (figures 18-19).

The Military industry was one of the major industrial efforts during the times of the former president Gamal Abdel Nasser. Egypt initiated with India and former Yugoslavia in the early sixties an ambitious project to manufacture planes, missiles, jet engines, and weapons. The Helwan HA-300 plane was manufactured in Helwan, and Egypt manufactured the first two missiles. Several military factories, which belong to the Ministry of Military Production, were built to meet the requirements of the Egyptian Armed Forces. ${ }^{29}$ Figures 20\&21 Show the first Cairo jet plane and one of the military factories in Helwan. The Seventh case of the industrial heritage contexts in Egypt is located at Qalyubia governorate, involving Industrial heritage factories for cotton with cotton ginnery machines left in a bad condition. Figures $22 \& 23$ show the old cotton factory and a laboratory for ginning cotton in governorate of Qaalyubia.

The eighth case of the industrial heritage contexts in Egypt is located at Akhmim a city in the Sohag Governorate of Uppe Egypt. The city is lamous for textiles manufacturing where traditional manufacturers use mechanical looms for producing textiles; and the city is a major textile center. The Handmade weaving industry is inscribed in 2020 (15.COM) on the Intangible Cultural Heritage List in Need of Urgent Safeguarding. ${ }^{.00}$ The mechanical looms are part of the industrial process and reveal the industrial heritage context. Figures $24 \& 25$ show the type of traditional machines used; another similar case of the Handmade weaving industry is located at Al-Q̨attan Carpet Factory in Cairo that continues to manulacture hand-made carpets using weaking machines sine its establishment in the 1930s in a factory" registered by the Egyptan Ninsiry of Culture in the "List of Egyptian and Coptic Antiquities," and it is now under the authority of the Ministry of Tourism and Antiquities and the owner of the factory. ${ }^{32}$ Figures $26 \& 27$ show the traditional looms in the factory

The archival photos of the industrial machinery in Egypt employ both history and significance of such types of heritage. The archival photos establish a historical record of the act of the machinery in Egypt during the $18^{\text {th }}$ and $19^{\text {th }}$ centuries. Notewor thy, the Voice of Cairo known as Sout El Qahira Company for Audio and Video, an Egyptian joint stock Company, one of the

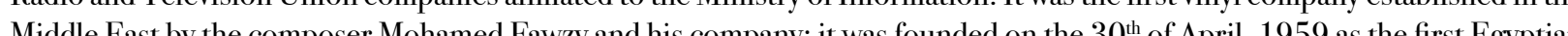

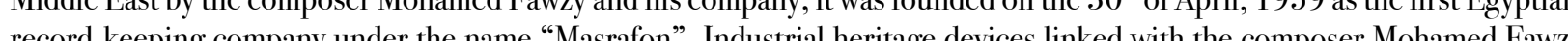
coling

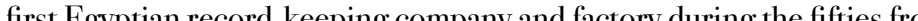

Setting a management plan for the Egyptian industrial heritage can contribute to safeguard, interpret, and promote this important aspect of Egypt's cultural heritage. The key starting point of preparing the strategy for managing the industrial heritage in
Egypt is the implementation of the Burra Charter Process ${ }^{4} ;$ which listed the stages for managing the cultural heritage and could be applied in the case of managing. Foyptian industrial heritage. Defining the value of the industrial heritage in Foypt require assembling data of the industrial heritage condition in both museums and industrial sites, as well as applying a special natured scientific - andytical research work that might face the increasing loss during heritage documentation. All factors and conceris

. 28 Environmental Action Plan by the Fayoum Governorate, Egyptian Ministry of E
www.eea.a.gov.eg/portals/0/ceaaReports/GovProfiles/final/Fayoum\%20Des.pdf
\& observation by the researcher during the visit to El Faivum in early 2020

29 President Gamal Abdel Nasser website, was set up in cooperation between the Library of Alexandria and the Gamal Abdel Nasser Foundation, accessed May 31, 2020, hitp://nasser.bibalex.org home/main.aspp?lang=ar

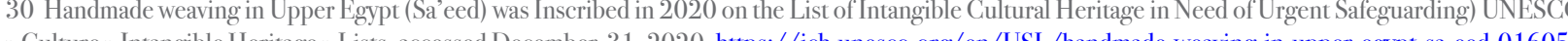
"Cun ure the 31 The Address of the factory is KOBRY EL KOBAD Zeitoun, Cairo Governoralc

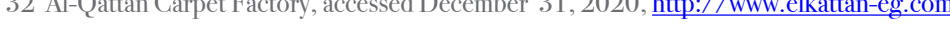

33 Makram Salama, a freelancer heritage collector, interested in the Egyptian cinema archive, Managed the project of safeguarding the collected old negative (3)

The-Burra-Charter-flow-chart.pdf 
affecting the definition of the current situation of the Egyptian industrial heritage or related machinery needs to be analyzed in terms of physical factors, the material condition of industrial machinery, conservation needs, level of authenticity, legal requirements for protecting industrial heritage and a list of interests of all stakeholders to reach the preservation process.

The phases of the strategy that could be set for managing Egyptian Industrial Heritage can be divided into the following within which the stakeholders and the Eoyptian community can participate in all phases of the process. The phases are:

1 - :Understand the significance and value of the industrial heritage in Egypt

2- Develop a policy to define, manage, and promote the Egyptian industrial heritage

3- Manage the Egyptian industrial heritage based on regulations.

\section{The foundations of the regulations can be introduced}

\section{with regard to the following aspects:}

* Forming a national committee to represent the managing policy of the Egyptian industrial heritage in terms of the guidelines of the International Committee for the Conservation of the Industrial Heritage, TICCIH, and a world organization for industrial heritage,

- All current Egyptian conservation laws should use specific terms to define and protect the industrial objects and industrial buildings in Egypt. Such laws should be considered when planning and during the process of deciinclude the public.

- Defining the industrial heritage sites in Egypt by promoting their outstanding industrial value, in order to play a key role in worldwide technical developments. Industrial heritage sites in Egypt with outstanding universal valEgyed

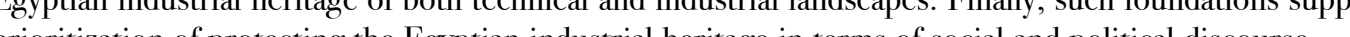

\section{Conclusion}

In the current context of the Egyptian industrial heritage, it has become apparent that it is important to define, set, and apply conservation, education, and interpretation procedures. Strengthening the three mentioned scopes can contribute to safeguarding the value of the industrial history of Egypt. All current Egyptian conservation laws ought to use specific terms to define and protect the mechanical objects and industrial buildings in Egypt. A strategy for managing the industrial heritage in Egypt Foyld bet by the gof the

Figures

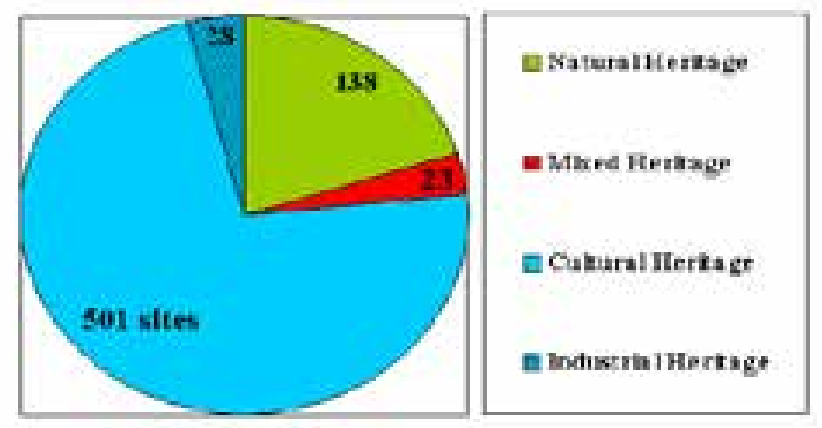

Industrial Heritage

embraces $5.3 \%$ of al

Cultural Sites and

$4 \%$ of all World

Heritage Sites.

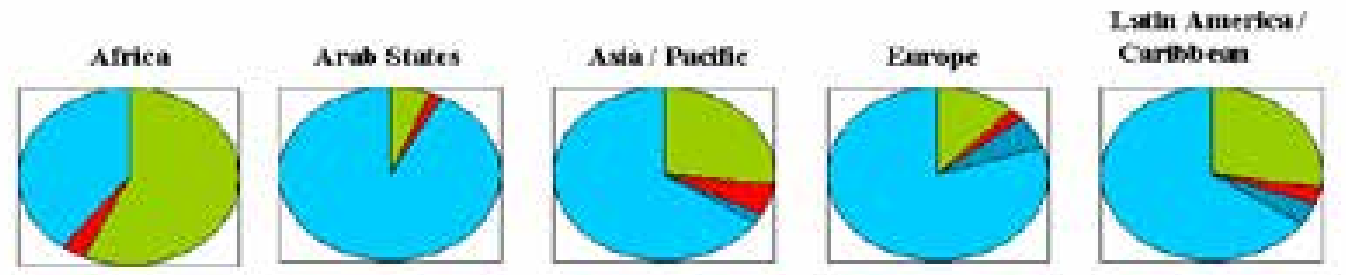

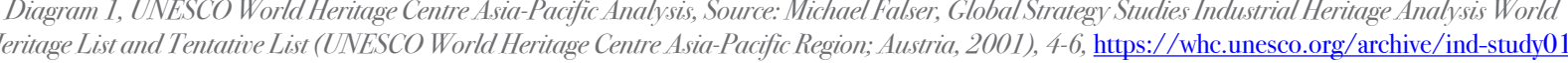

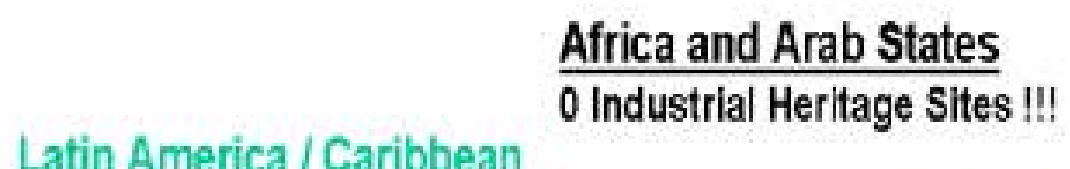

Latin America / Caribbean 4 Industrial Heritage Sites

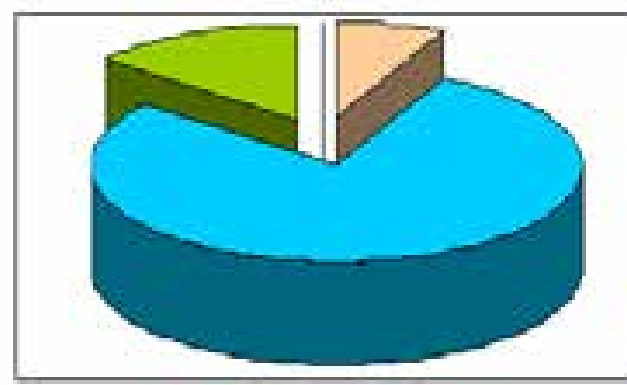

Assia / Pacific

Industrlal Heritage Siftes

Europe / North America

22 Industrial Heritage Sites

Diagram 2 UNESCO World Heriage Centre Asia-Pacific Analyses, Africa \& Arab states including Egypt does not have any in dessrial heritage sites included

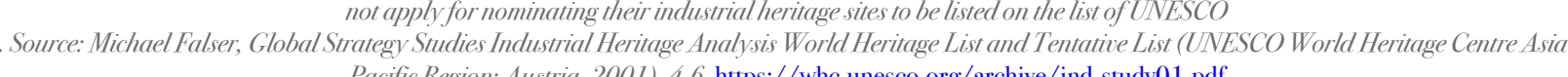
Pacific Region; Austria, 2001), 46, h.tps://whc.unesco.org/archive/ind-sudy01.pdf 


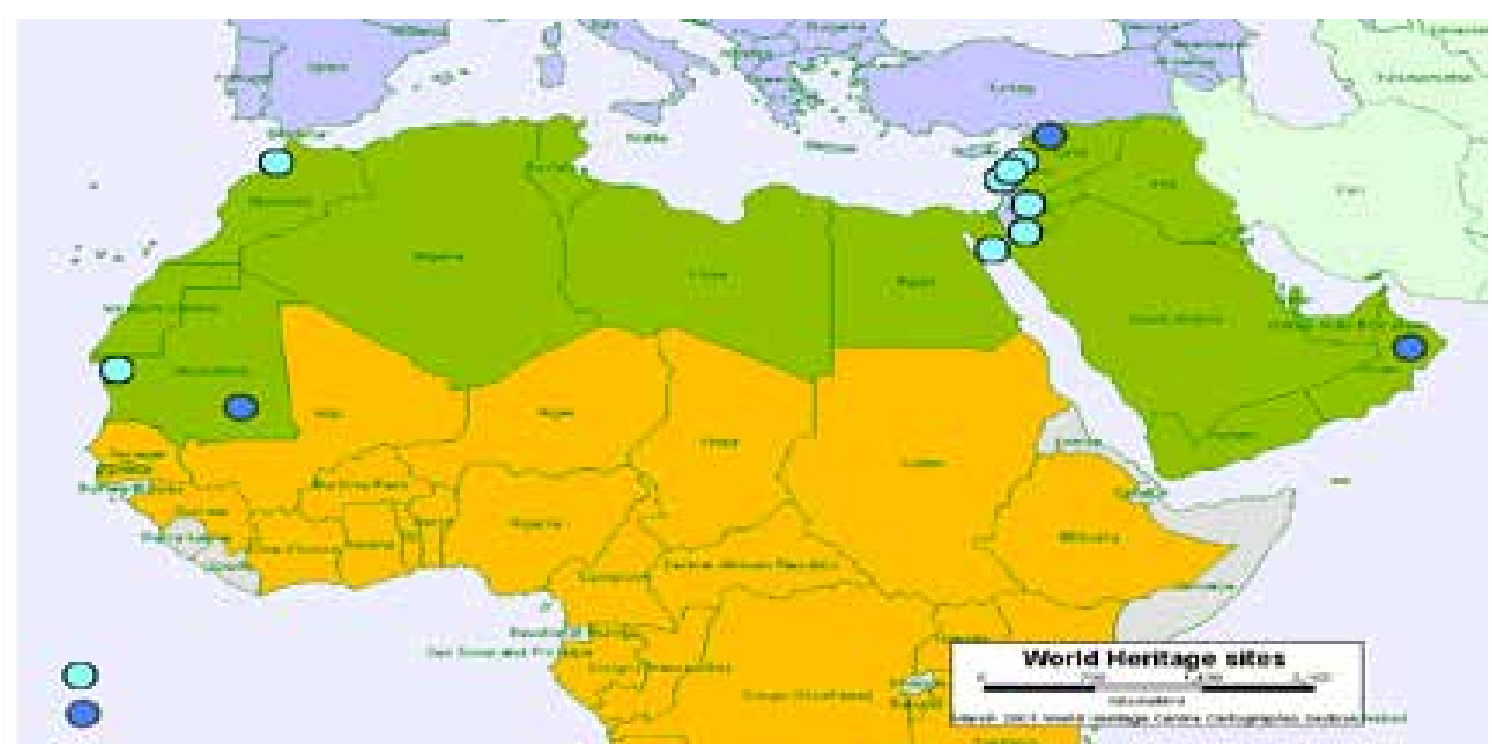

Figure I Shous she map of Tentaive Industrial World Herituge Sies in the Arrab States UNESCO World Heritage Centre Asia-Pacific Analyses. Source:

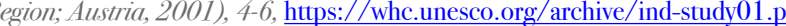

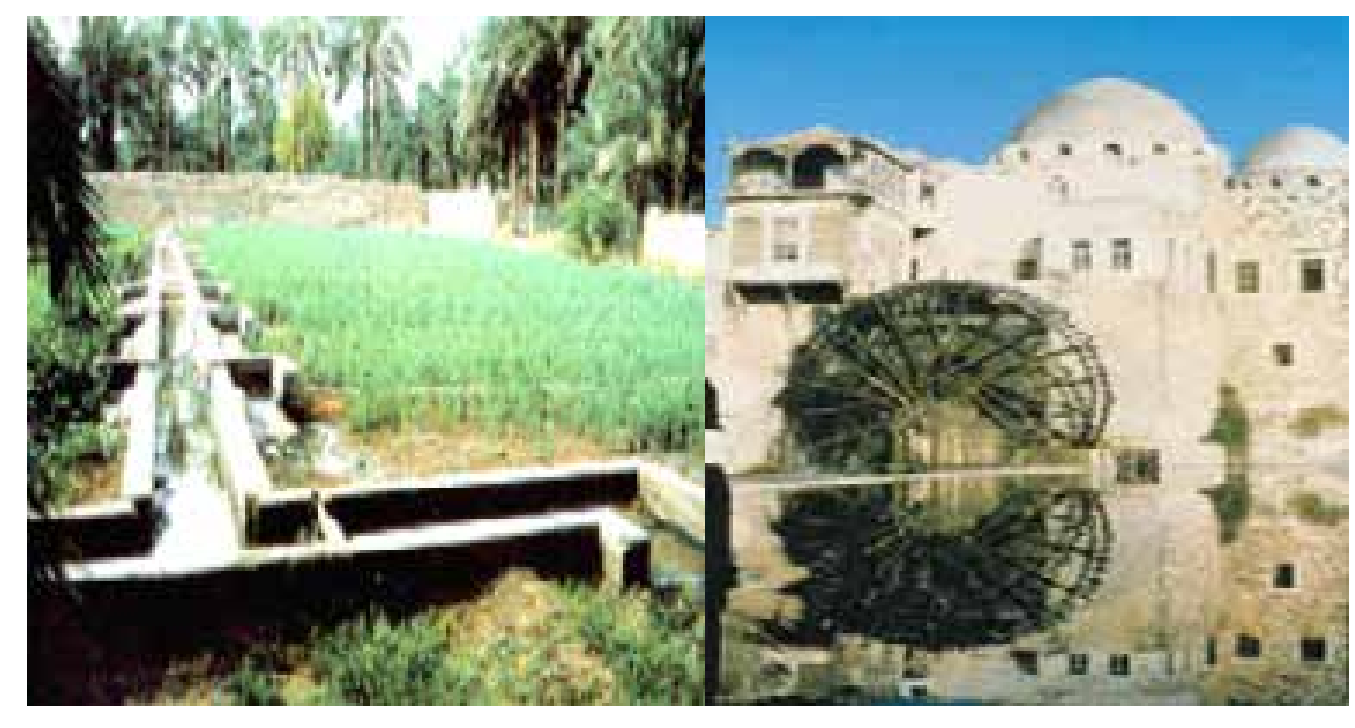

Figures 2-3 The first is The Commercial center for merallurgical industry of gold, iron and copper in Mauritunic, the second is Al "Affal" ground and Source: Michael Falser, Global Strategy Sudies Industrial Heritage Analysis World Heritage List and Tentative List (UNESCO World Heritage Centre Asia Pacific Region; Austria, 2001), 4-6, https:// whc. unesco.org/archive/ind-study01.pdf

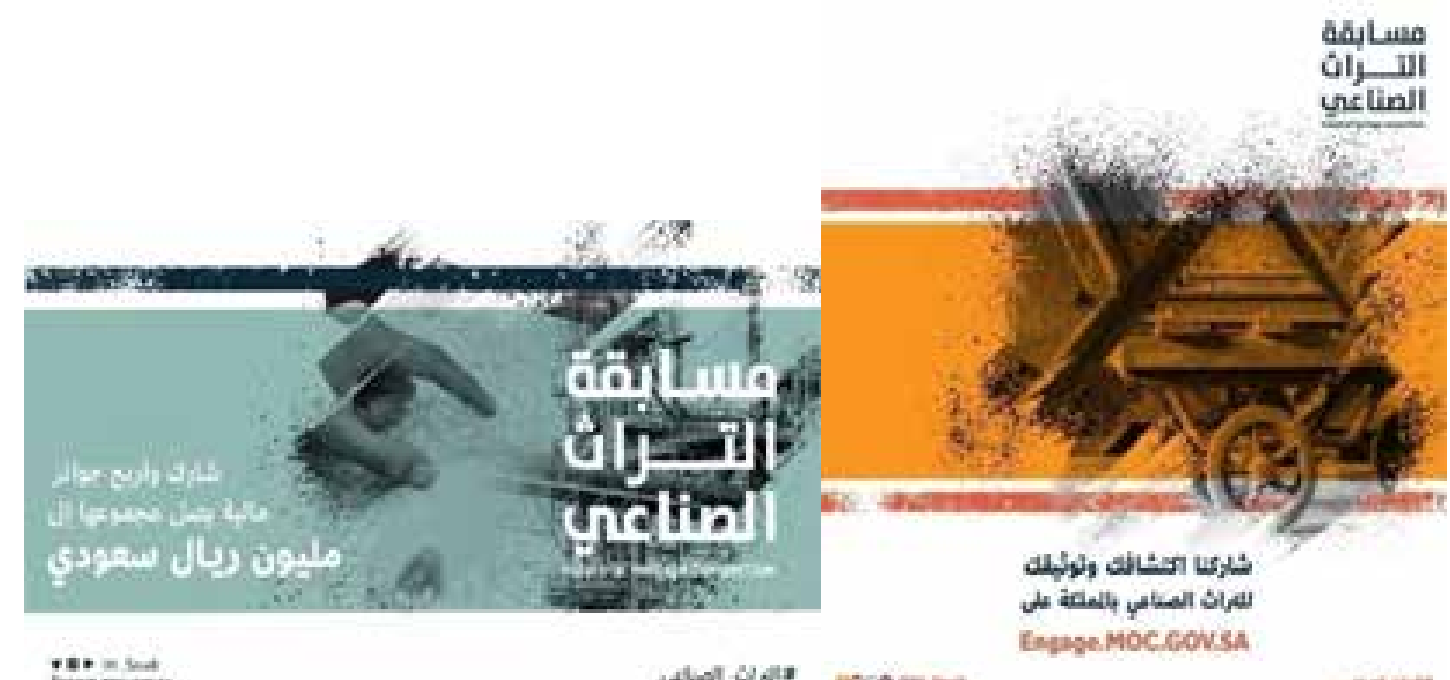

Figures 4-5.5 shous she announcement of the Saudi Ministry of cullure competition for documenting the industrial heritage in Saudi Arabiai in the country

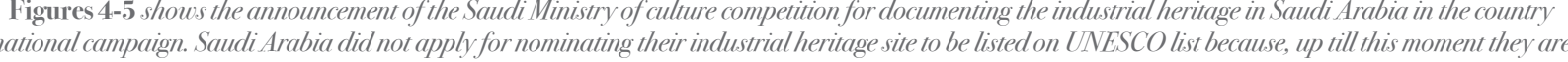

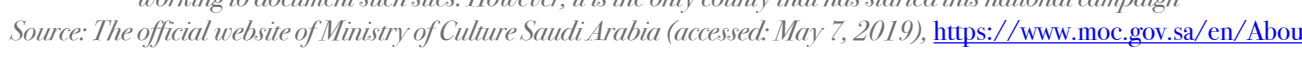

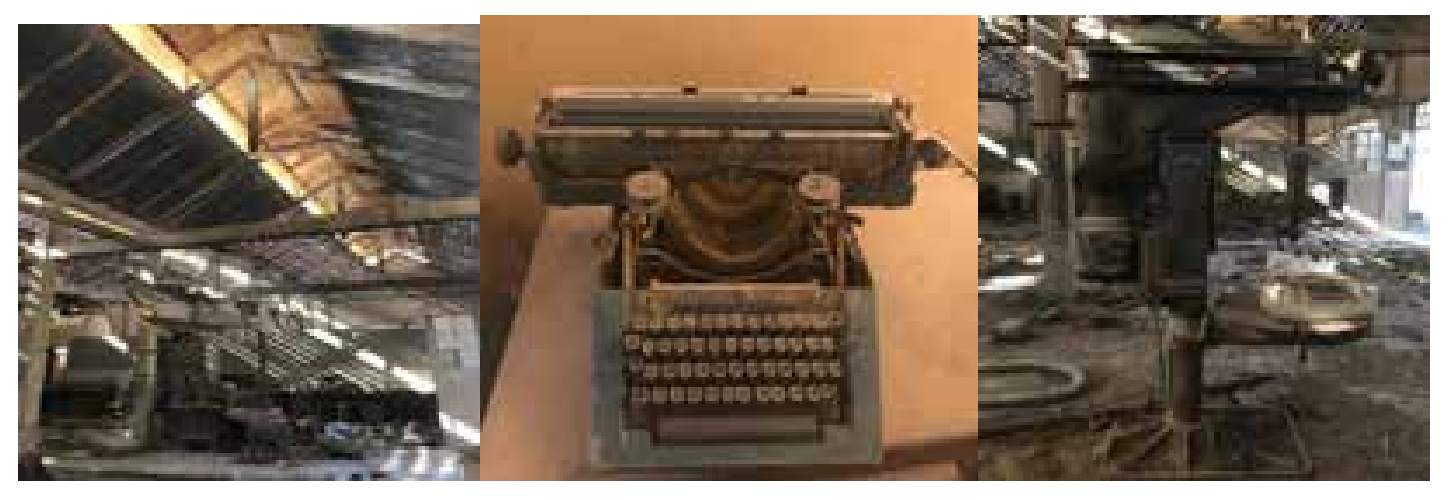

Figures 6-7-8 The current situation of one of the old Phosphate factories of Al Qusayr OShreenMohmed, 8 August 2019

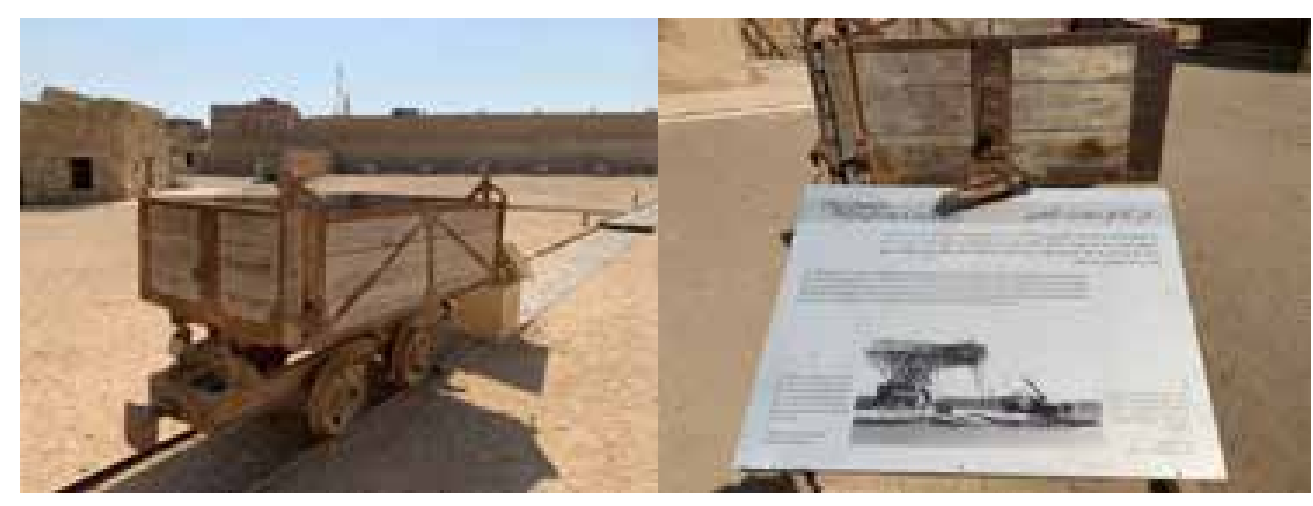

Higures 9-10 The carriages shat were used to transport phosphates in the early 20 " century Al Qussayr citadel OShreen Mohmed, 8 Alugust 2019 


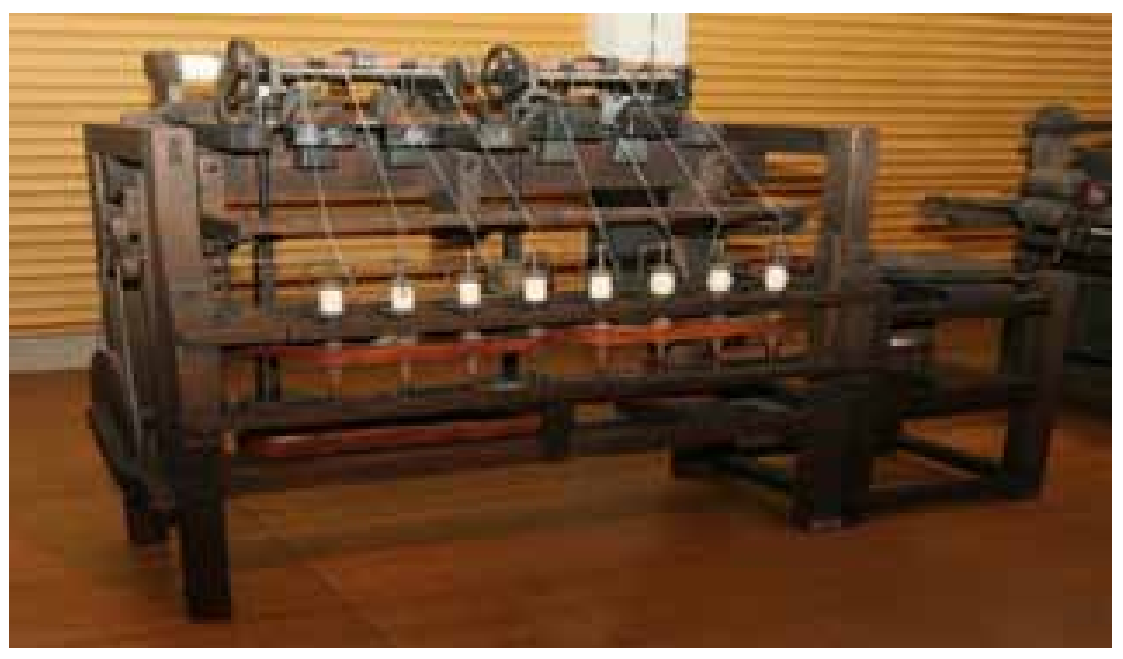

Figures 11One of the industrial heritage machines used in Egypt in Cotton spinning; made by the British Sir Richard Arkwright Eric Evans

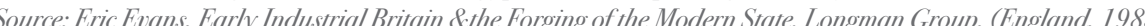

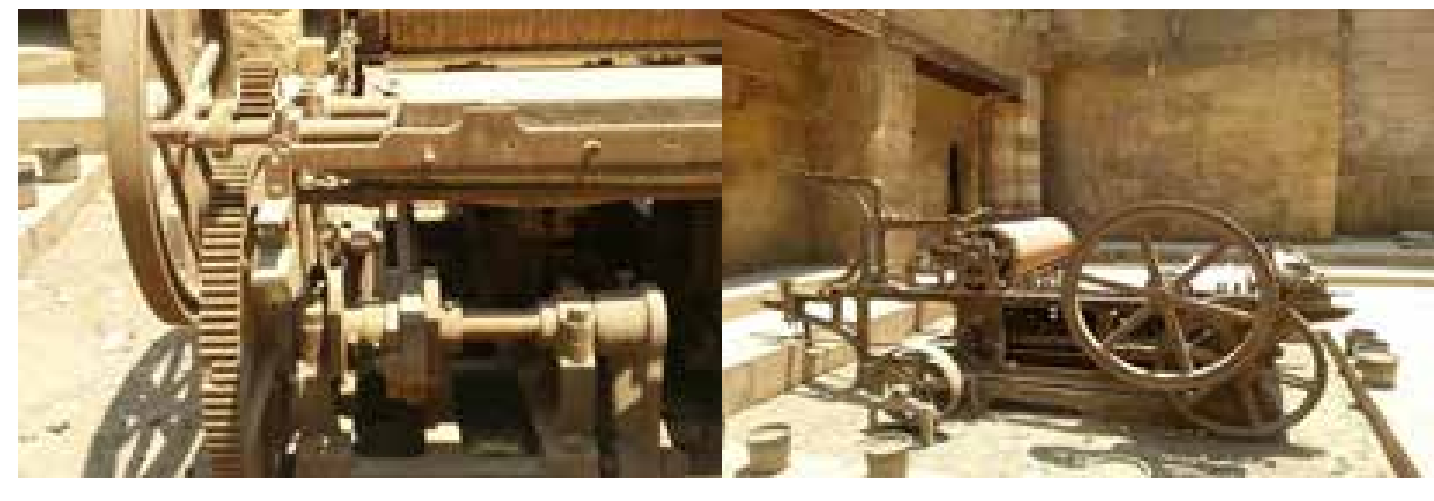

Figures 12-13 The 19th - century printing machine in one of the old Islamic schools at Al-Azhar Street; currently their location is under authority of the Historic Cairo Project Sector ${ }^{36}$ OShreenMohmed May 7,2018
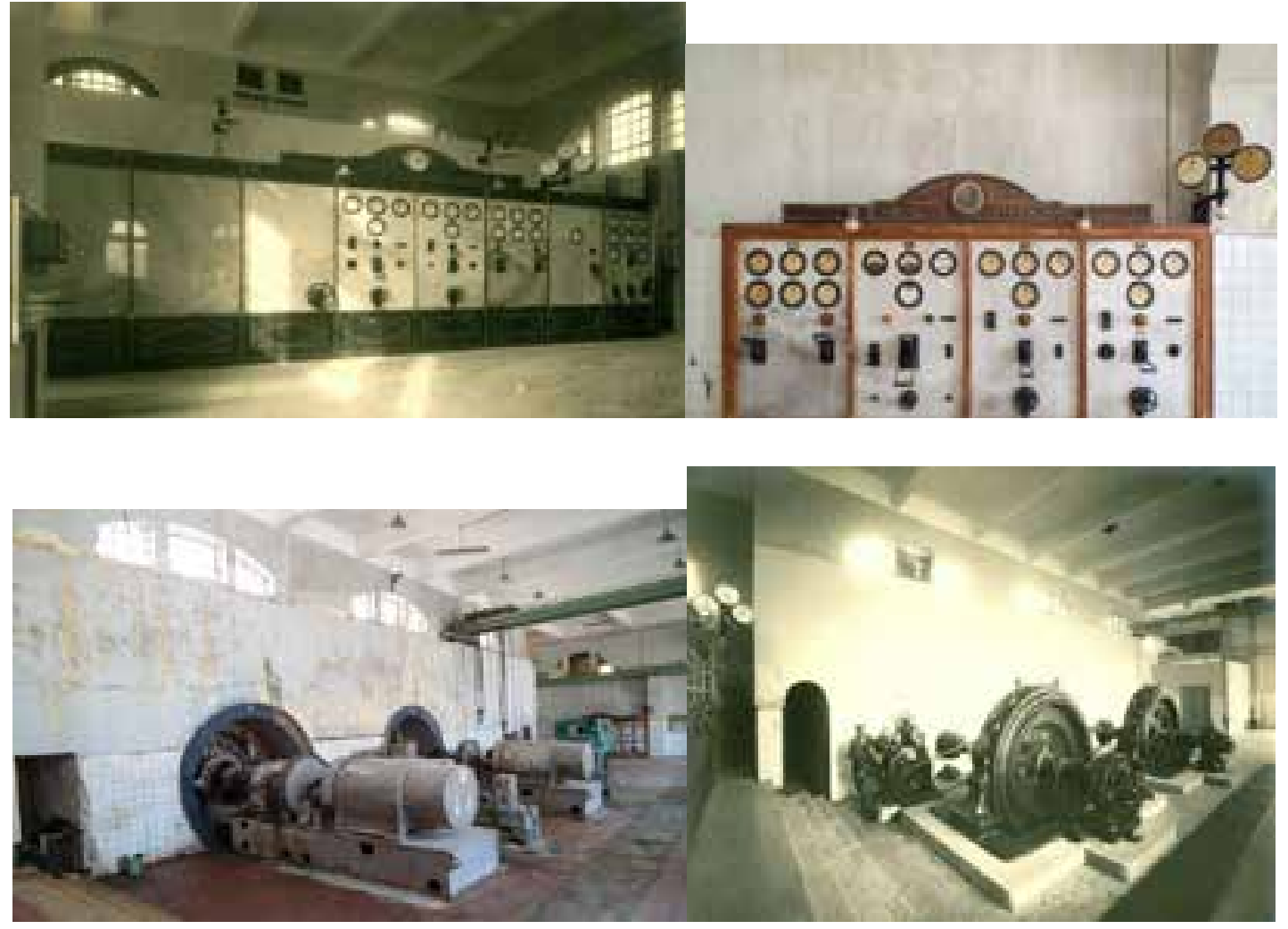

Figures 14-17 the old and new urb bine motors at El Faiyum Power Station OShreenMohmed, Jamuary 9, 2020. \& explore Fayoum, accessed May 31, 202

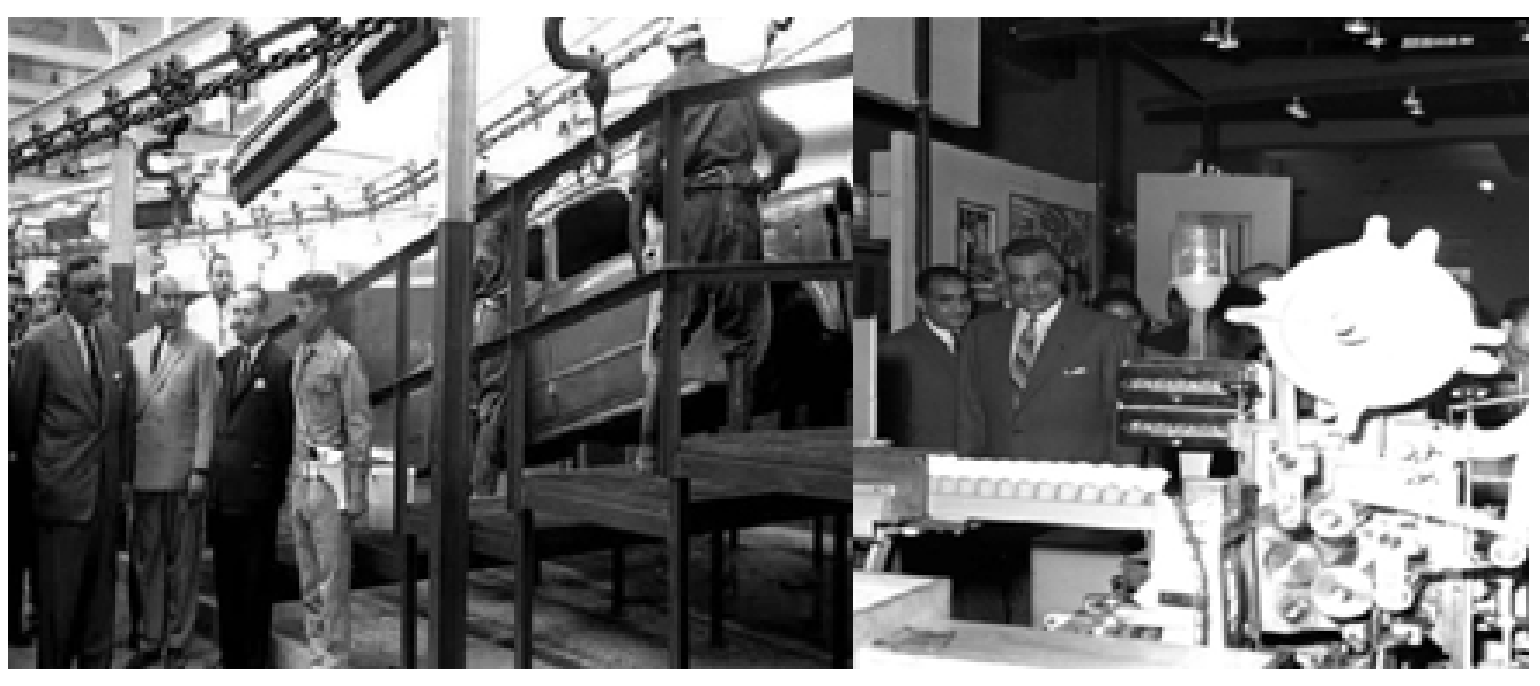

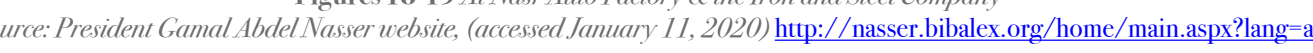




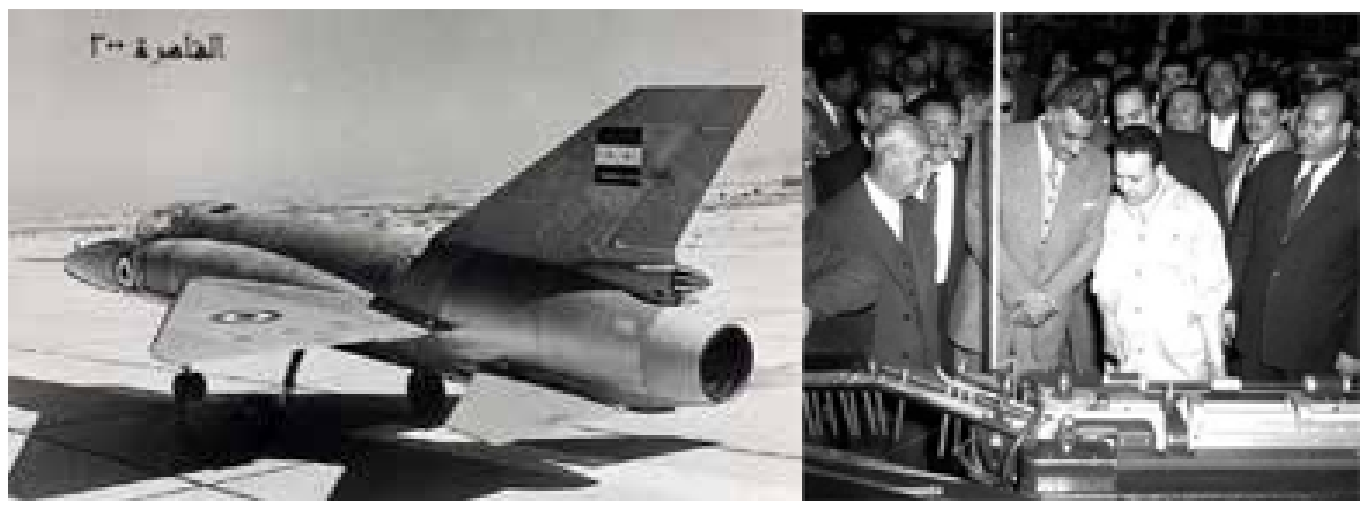

Figures 20-21 One of the military factories in Helwan and the first Cairo jet plane

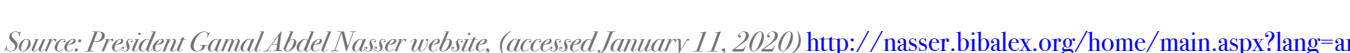

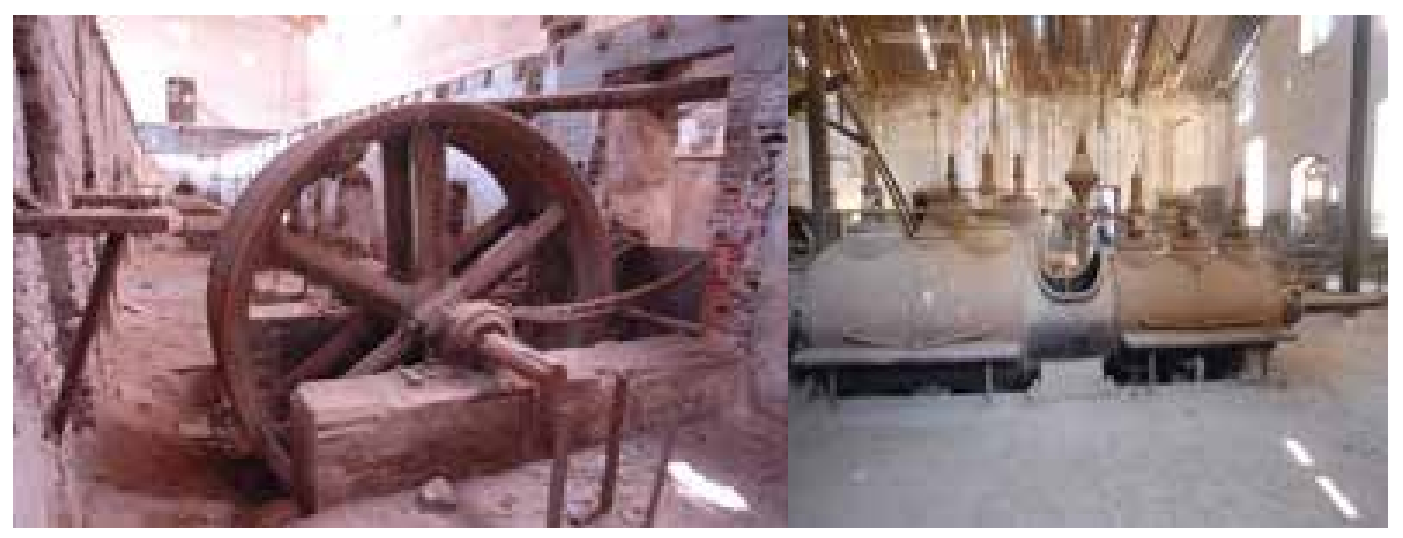

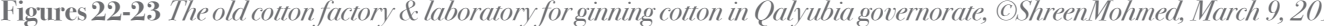

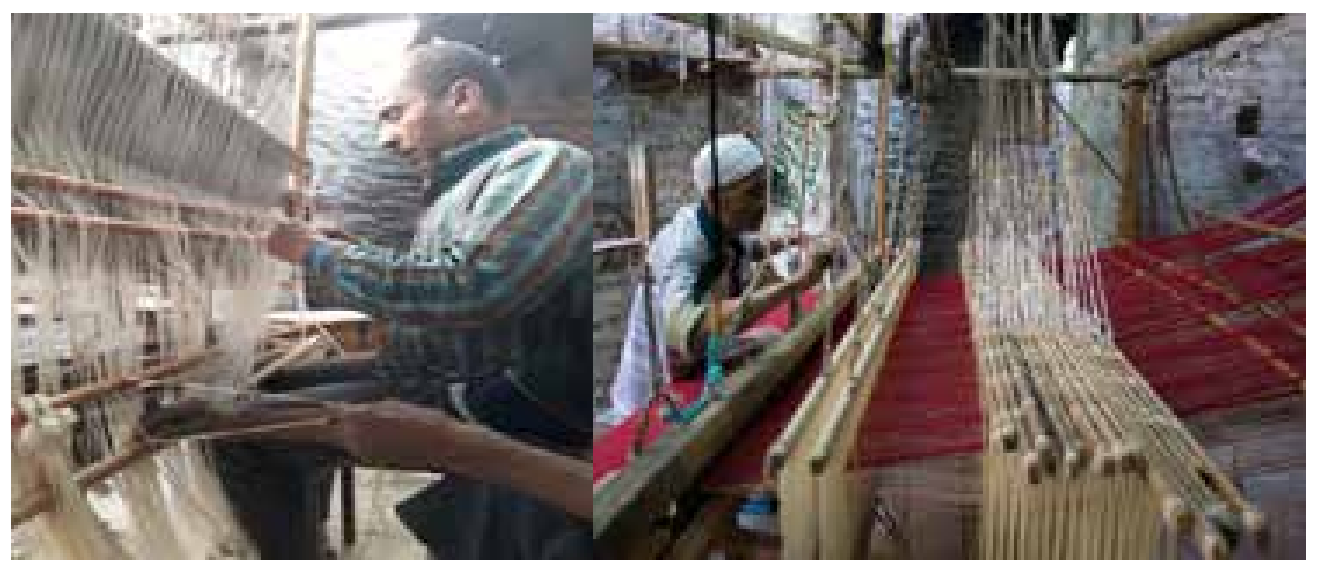

Figures 24-25. Mechanical looms in Akhmim, OShreenMohmed, December 7, 2019
Mapping

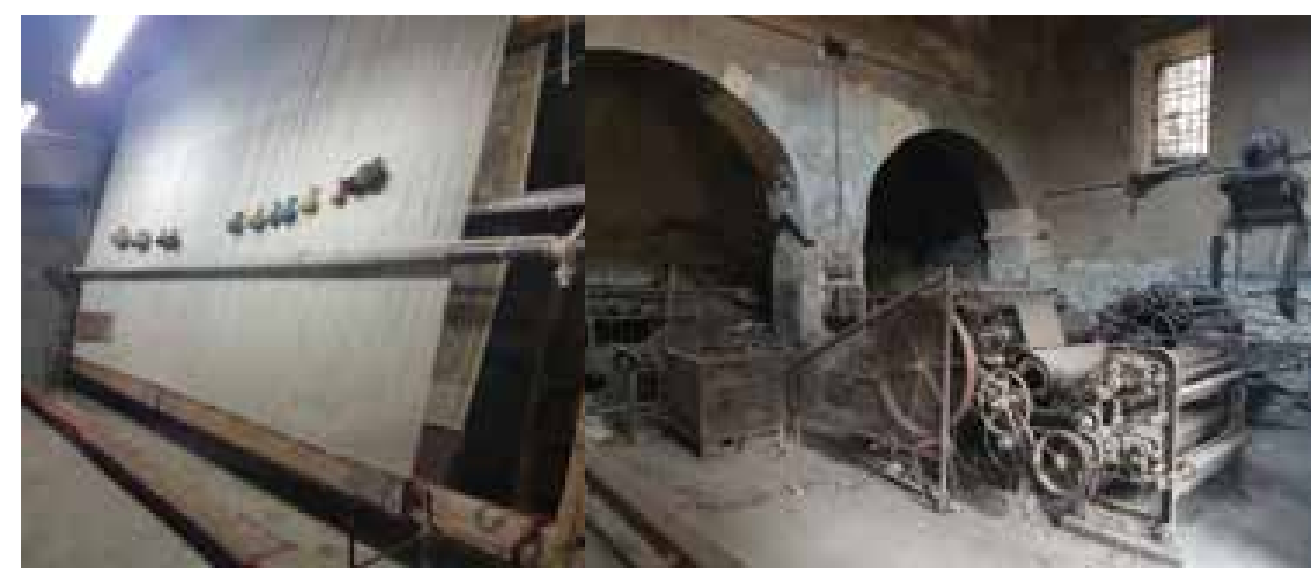

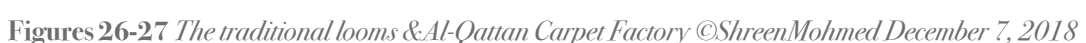
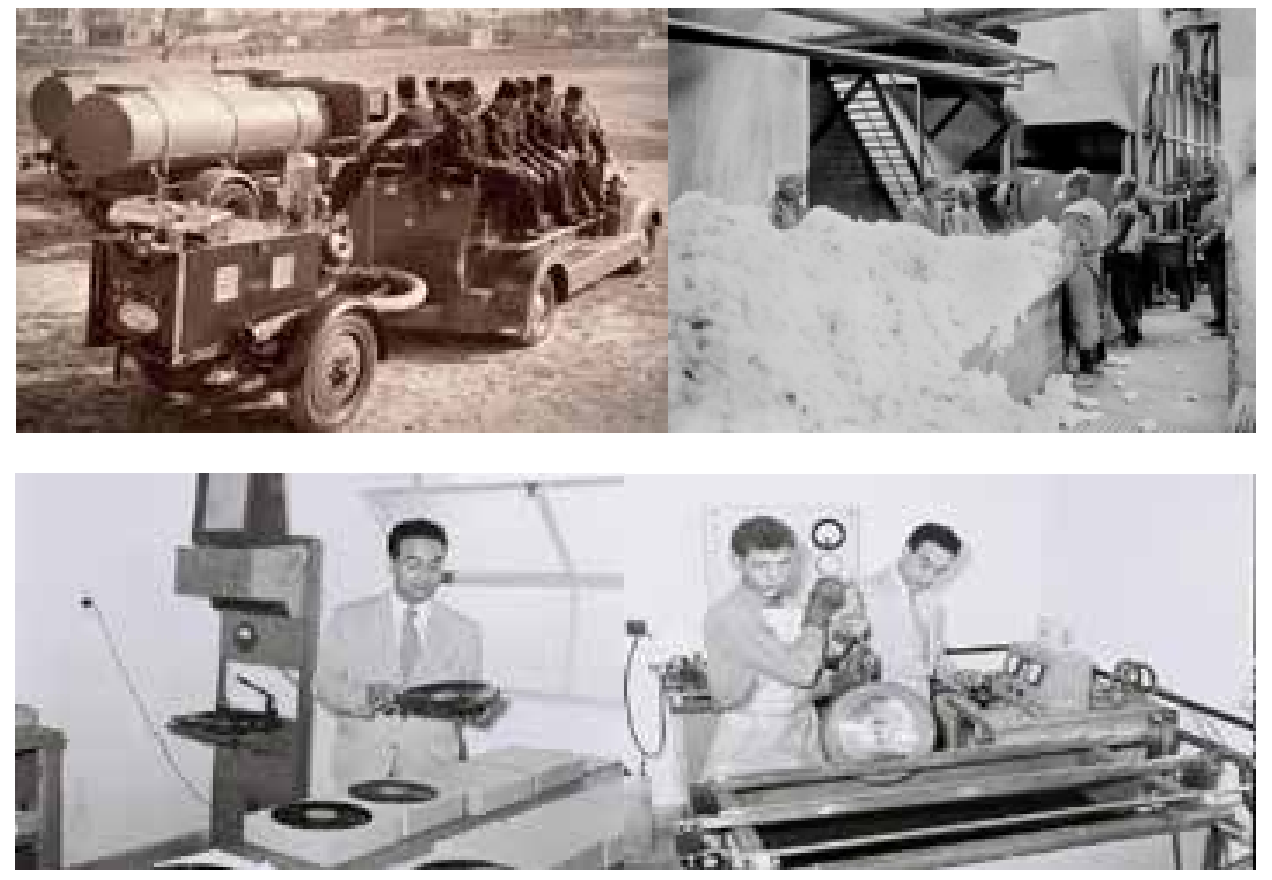

Figures 28-31 the archival photos of objects with old industrial equipment, Source: Egypt archive, accessed 26/3/2020, http://archivegypt.com/ 


\section{Bibliography:}

- Arkwright Richard (1732 - 1792)”. BBC. accessed May 31, 2020,https://www.bbc.co.uk/history/historic figures/ arkwright_richard.shtml

- Bin Farhan, Badr bin Abdullah, the Saudi Minister of Culture, an association for the preservation of Industrial Heritage( Ministry of Culture Saudi Arabia:2020), accessed October 31, 2020. https://www.moc.gov.sa/en/About

- Burra Charter Process, (Australia ICOMOS Incorporated: 2017), 1-10, accessed May 31, 2020, https://australia.icomos. org/wp-content/uploads/The-Burra-Charter-flow-chart.pdf

- De Dirigenten De Jong Van De Herinnering. Musealisering en nationalisering van de volkscultuur in Nederland 18151940, (Nijmegen: Sun, 2006), 85

- Environmental Action Plan Fayoum Governorate, Egyptian Ministry of Environment \& Fayoum Governorate EMU, accessed May 31, 2020, http://www.eeaa.gov.eg/portals/0/eeaaReports/GovProfiles/final/Fayoum\%20Des.pdf

- Falser Michael. Global Strategy Studies Industrial Heritage Analysis World Heritage List and Tentative List, UNESCO World Heritage Centre Asia-Pacific Region, 2001.

- Historical Cairo project reports, accessed May 31, 2020, https://whc.unesco.org

- Mamdouh Dina Nassar. Sharaf Eldin Shahira, A new life for the industrial heritage of Minet el-Bassal at Alexandria (Wiadomości Konserwatorskie , The Journal of Heritage Conservation: 2013) 2-6.

- Oevermann, Heike.Industrial heritage management in the context of urban planning (Georg-Simmel-Center for Metropolitan Studies Berlin, Germany,Big Stuff, accessed October 31, 2019, https://bigstuff.omeka.net/items/ show $/ 17$,

- President Gamal Abdel Nasser website, was set up in cooperation between the Library of Alexandria and the Gamal Abdel Nasser Foundation , accessed May 31, 2020, http://nasser.bibalex.org/home/main.aspx?lang=ar

- Shura Council, Fifth Ordinary Session, Report of the Production and Manpower Committee on Industrial Policy in Egypt,( government Media office Egypt: 1985)5-4

- TICCIH The Nizhny Tagil Charter for the Industrial Heritage (Moscow, 2003),1- 4, accessed December 10, 2020 https://www.icomos.org/18thapril/2006/nizhny-tagil-charter-e.pdf

- The National Plan for Industrial Heritage (Ministry of Culture of Spain: 2011), accessed October 31, 2019, http://www. culturaydeporte.gob.es

- The Egyptian Ministry of Trade and industry- main mission, accessed May 31, 2020, http://www.mti.gov.eg/English/ Pages/default.aspx

- The Egyptian Ministry of Antiquities, accessed May 31, 2020,http://www.antiquities.gov.eg.

- The official site of the Ministry of the public sector in Egypt, accessed May 31,2020, http://www.sis.gov.eg/Story/99611/ Ministry-of-Public-Business-Sector

- UNESCO", The United Nations Educational, Scientific and Cultural Organization, accessed December 10, 2020, https:// en.unesco.org/

- UNESCO World Heritage Centre, accessed May 31, 2020,http://whc.unesco.org/

- Yegipyet L.A. Fridman's. Capitalist development in Egypt\& the Egyptian working class 1939- 1882, trans.Dr. Zuhdi Al-Shami (New World Publishing House: Egypt, 1985), 75. 